\title{
Ecology of Mesamphiagrion laterale (Odonata: Coenagrionidae): abundance, reproduction and interactions with co-occurring species
}

\author{
Fredy Palacino-Rodríguez ${ }^{\mathrm{a}, \mathrm{c} *}$, Mariano Altamiranda-Saavedra $^{\mathrm{b}}$, Diego Andrés Palacino ${ }^{\mathrm{c}}$ and \\ Andrea Carolina Penagos ${ }^{\mathrm{c}}$ \\ ${ }^{a}$ Biology Research Group (GRIB), Department of Biology, Universidad El Bosque, Bogotá, Colombia; \\ ${ }^{b}$ Institución Universitaria Politécnico Colombiano Jaime Isaza Cadavid, Medellín, Colombia; ${ }^{c}$ Research \\ Group on Odonates and other arthropods of Colombia (GINOCO), Acarology Research Center, Bogotá, \\ Colombia
}

(Received 11 October 2019; accepted 6 March 2020 )

\begin{abstract}
The behavior of Mesamphiagrion laterale (Selys, 1876) is described based upon 2430 hours of observation. A total of 2820 individuals were observed for 270 days from 2014 to 2015 using mark-recapture. Probabilities of resight, highest reproductive activity, time-perch and time of perch-temperature were statistically analyzed. Mesamphiagrion laterale is not a territorial species, the individuals perch on grass, trees, garbage, ground, and rocks, they feed on hemipterans, mosquitoes, spiders and other damselflies, and are prey to spiders and birds. Conspecific siege and interspecific interactions by perch were observed. No courtship was observed. During tandem, which lasted for 3-90 min, the ventral side of the male's abdominal segment 2 was in contact with the female's abdominal segments 8-10 until a wheel was formed. We observed three tandem pair combinations: sexually mature males and females, immature males with mature females, and immature males and females. While copulation lasted from 7 to $20 \mathrm{~min}$, oviposition lasted from 12 to $15 \mathrm{~min}$. Irrespective of male presence, oviposition occurred in submerged or emerged areas of Eichornia crassipes. We recorded the highest reproductive activity between 12:00 and 12:35 (Colombia Time-COT, UTC-5). Above $20^{\circ} \mathrm{C}$, a larger perching area close to the water allows more reproductive events. However, a more extensive canopy cover impedes achieving optimal reproductive temperatures. Species interactions within this community may be explained by temporal and spatial niche partitioning.
\end{abstract}

Keywords: damselfly; Colombian Andean; behavior; insects; Neotropic; dragonfly

\section{Introduction}

As a response to current threats to biodiversity, it is critical to generate information to study and understand the evolutionary and ecological processes surrounding species (Chapin, Matson, \& Vitousek, 2011; Rosenzweig, 2001). This is particularly critical for Neotropical ecosystems, wherein organisms such as damselflies are diverse and abundant, but whose ecology and behavior remain poorly understood (Cordero-Rivera \& Stoks, 2008).

Within the Coenagrionidae family of damselflies, there seems to be a considerable variation in reproductive behavior (Altamiranda-Saavedra, Palacino-Rodríguez, \& Lobo-Hernández, 2014;

*Corresponding author. Email: palazinofredy@unbosque.edu.co 
Alves-Martins, Del-Claro, \& Jacobucci, 2012; Córdoba-Aguilar, Serrano-Meneses, \& CorderoRivera, 2009; Guillermo-Ferreira \& Del-Claro, 2011, 2012; Loiola \& De Marco, 2011). As these reproductive behaviors occur at the breeding site and at specific times, it is possible to record them as they occur to determine the environmental conditions that either limit or encourage reproduction (Lambret \& Stoquert, 2011). One important behavior is perching, which is related to feeding (Baird \& May, 1997; Gorb, 1994), energy conservation (Baird \& May, 1997; May, 1984), reproduction (Corbet, 1999; Corbet \& May, 2008), and thermoregulation (Baird \& May, 1997; May, 1976, 1978). This behavior helps to classify odonates into fliers and perchers. When active, fliers remain in flight, while the perching species take short flights and spend several hours perched on breeding sites (Corbet, 1999). The behavior of species inhabiting the tropical Andes remains poorly understood. This is particularly evident for the 11 species within the poorly known Mesamphiagrion genus, which inhabits lentic or lotic ecosystems, from degraded to well-preserved areas. For some Mesamphiagrion species, sporadic observations by De Marmels $(1988,1997)$ and Bota-Sierra \& Wolff (2013) have recorded some behaviors about intraspecific interactions, but detailed studies have not been conducted.

Mesamphiagrion laterale (Selys, 1876) is a medium-sized coenagrionid damselfly inhabiting near reservoirs, small lakes, and marshes, impoundments and swamps, with grasses and bushes that they use for shelter (Álvarez-Covelli, Álvarez-Covelli, \& Palacino-Rodríguez, 2015; BotaSierra \& Wolff, 2013) at the Andean eastern mountain range in Colombia. Mature adults show brown or black colors with light blue over postocular spots, thoracic stripes, the internal region of the femur, and the dorsal region of 7-9 (males, Figure 1a) or 8 (females, Figure 1a) abdominal segments, and their wings are hyaline. Juveniles have red-orange coloration on abdominal segments 1-3 (Figure 1b, c). Plasticity is present in the posterior lobe of the pronotum and ventrobasal process of male cercus and the color of abdominal segment 8 in females. Mesamphiagrion laterale is a very common species near Bogotá that can be included as a model for genetic, behavioral, and systematic studies. However, our knowledge about the behavior of this
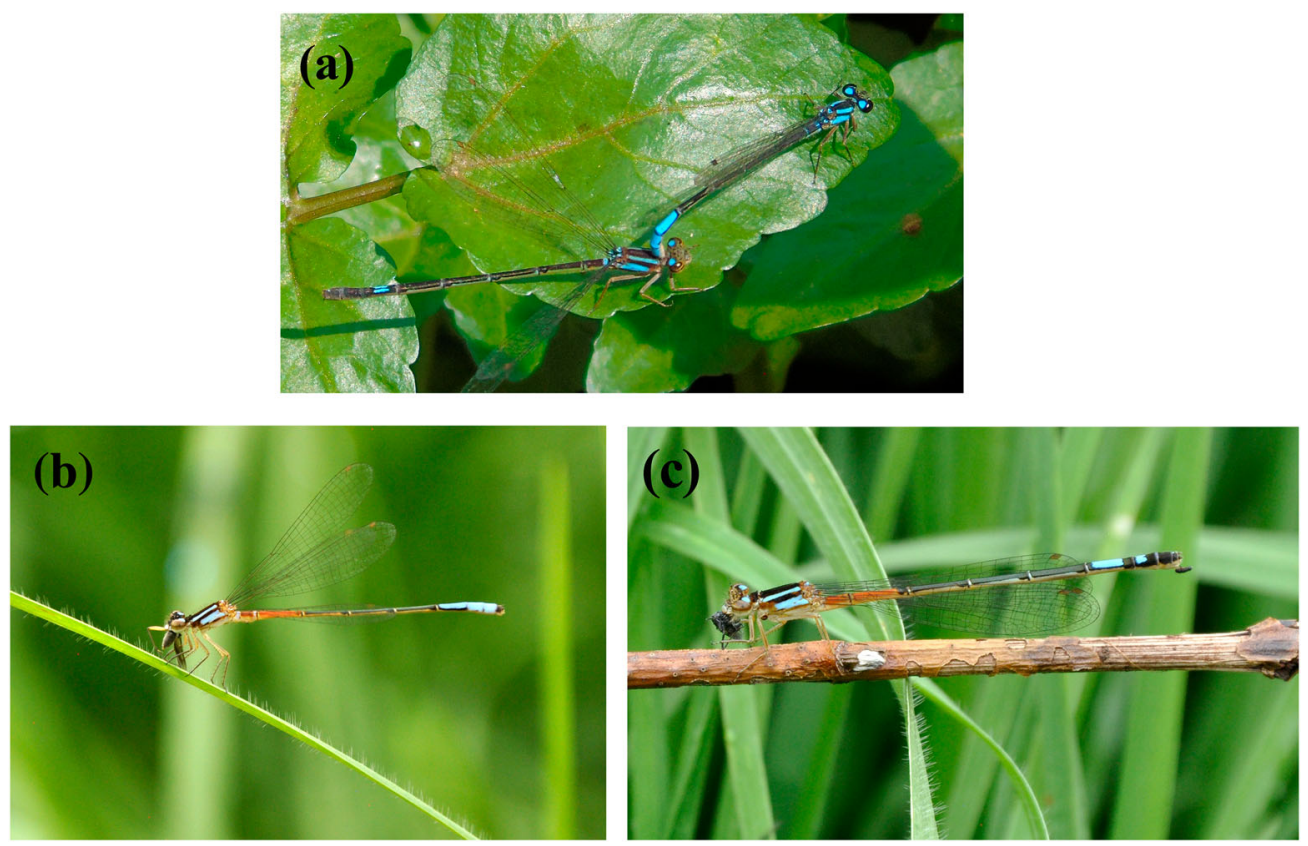

Figure 1. Adult of Mesamphiagrion laterale. (a) Mature male (right) and mature female (left). Photo: M. Silva. (b) Juvenile male. Photo: F. Palacino-R. (c) Juvenile female. Photo: F. Palacino-R. 
species is scarce. For this reason, our aim was to describe basic information about the behavior and interactions of that species. Thus, the objective of this study was to observe this species at the breeding site: (i) the daily abundance of individuals near waterbodies; (ii) differences in the type and frequency of the behavior (reproductive and non-reproductive) by location; (iii) differences between time used to perch in different types of perch; and (iv) possible relationships between time used to perch and the environment temperature.

We proposed these objectives considering that the high tolerance of $M$. laterale, including their thermos-conformist condition and a high competitive capability, give to this species the ability to be generalist, to tolerate a broad set of environmental conditions and to use a wide range of resources. As has been reported for other insects, a good diet permits high tolerance (Lee, Simpson, \& Wilson, 2008; Sisodia \& Singh, 2012), which is possible in M. laterale, given the diversity of herbivorous prey in their habitat. Therefore, strong variations in daily abundance and differences in the type, frequency and time of their behaviors are expected.

\section{Materials and methods}

\section{Study area}

This study was carried out at two municipalities (Guasca and Guatavita) of the Cundinamarca Department in the Andean eastern mountains range (Figure 2). The data recording was done at lentic habitats of three locations: (i) Crimea Pond (4.8333N 73.9166W, $2690 \mathrm{~m}$ asl); (ii) El Abuelo wetland (4.8166N 73.9336W, $2600 \mathrm{~m}$ asl); and (iii) Tominé Dam (4.9333N 73.9333W, $2600 \mathrm{~m}$ asl). These locations were selected since these provide heterogeneous conditions

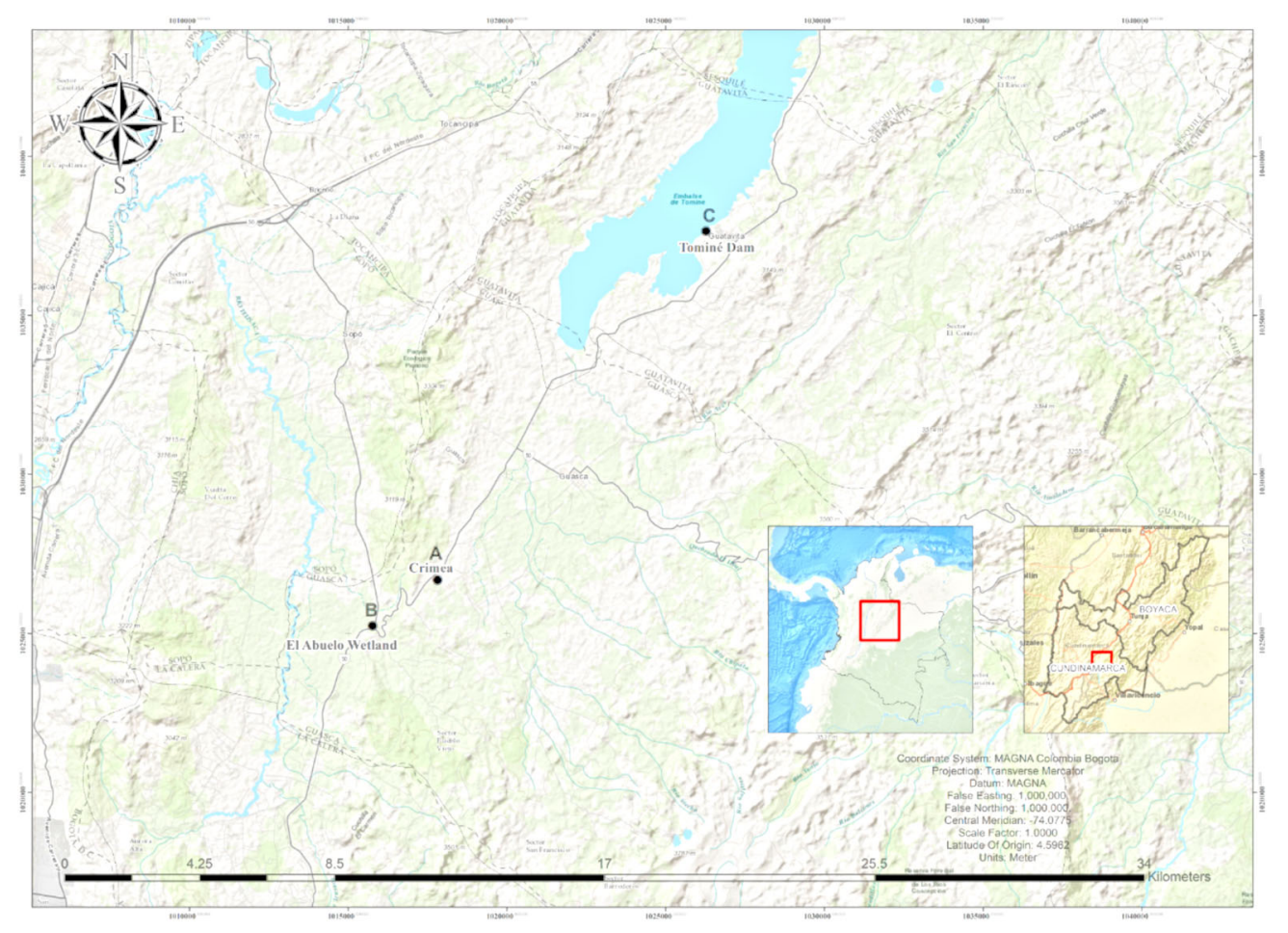

Figure 2. Map showing location of Crimea, El Abuelo and Tominé. 
Table 1. Mesamphiagrion laterale sample size, recapture rate, and probability of resighting per habitat type.

\begin{tabular}{|c|c|c|c|c|c|c|c|c|c|c|c|c|c|}
\hline & \multicolumn{2}{|c|}{$\mathrm{N}$} & \multicolumn{2}{|c|}{$\mathrm{RC}$} & \multicolumn{2}{|c|}{ PR } & \multirow[t]{2}{*}{$\mathrm{P} 1$} & \multirow[t]{2}{*}{$\mathrm{P} 2$} & \multirow[t]{2}{*}{$\mathrm{M}^{*}$} & \multirow[t]{2}{*}{$\mathrm{F}^{*}$} & \multirow[t]{2}{*}{$\mathrm{PA} \mathrm{m}^{2}$} & \multirow[t]{2}{*}{$\mathrm{CC} \%$} & \multirow[t]{2}{*}{$\mathrm{MC} \%$} \\
\hline & M & $\mathrm{F}$ & M & $\mathrm{F}$ & M & $\mathrm{F}$ & & & & & & & \\
\hline Pond & 705 & 200 & 175 & 35 & 0.25 & 0.17 & & & & & 500 & 10 & 90 \\
\hline Wetland & 700 & 231 & 525 & 161 & 0.75 & 0.70 & & & & & 400 & 10 & 70 \\
\hline Impoundment & 734 & 250 & 587 & 150 & 0.80 & 0.60 & & & & & 1500 & 70 & 70 \\
\hline
\end{tabular}

$\mathrm{N}$, number of $M$. laterale individuals; RC, individuals recaptured; PR, probability of resighting; PA, area for perch; P1, significance between males and females of the same locality; P2, significance between localities; $\mathrm{M}^{*}$, males, comparing all localities; $\mathrm{F}^{*}$, females, comparing all localities; CC, canopy cover; $\mathrm{MC}$, macrophyte cover

(Table 1) for the species under study. Thus, it is possible to determine whether $M$. laterale varies their frequency or duration of behavior depending on variations between locations. This region is characterized by temperatures ranging between $-2^{\circ} \mathrm{C}$ and $25^{\circ} \mathrm{C}$ and an annual precipitation between 600 and $2000 \mathrm{~mm}$ (IDEAM, 2017). In general, the region has a monomodal rainfall, with a dry period that goes from December to March, June, July, and August, and a rainy season for the remaining months (IDEAM, 2017). The total area sampled was $500 \mathrm{~m}^{2}$ around the Crimea Pond, $400 \mathrm{~m}^{2}$ for El Abuelo wetland and $1500 \mathrm{~m}^{2}$ at the Dam. Those areas were selected as, prior to this study, we visited these areas to ascertain that the measurements in such areas correspond to the total area of dispersion used by $M$. laterale to perch in each habitat. The predominant vegetation in these areas was kikuyu (Pennisetum clandestinum Hochst. ex Chiov), Eichornia crassipes (Mart.) Solms, 1883, Acacia sp., Eucalyptus sp., Commelina sp., and Brachiaria sp.

\section{Data collection}

In this study, maximum daily activity was considered as the number of individuals present on the breeding site at a given time (reviewed by Lambret \& Stoquert, 2011). This definition mainly focuses on observing reproductive behavior at these sites. Fieldwork was done from 09:00 to 18:00 hours for 270 days, from 30 November 2014 to 14 November 2015. Non-marked damselflies were captured with aerial nets and individually marked with a fine-tip Sharpie ${ }^{\circledR}$ black marker on the right forewing using four-digit numbers starting from 0001 . We used this markrecapture method as previous studies have shown that there is no statistical effect on recaptured individuals when using different colors or alar locations to mark them (Álvarez-Covelli et al., 2015; Palacino-Rodríguez \& Contreras-Sánchez, 2014). A total of 2430 h was used for observation, collecting observational data every $810 \mathrm{~h}$ at each sampled site $(410 \mathrm{~h}$ in dry season and 400 $h$ in rainy season).

To record data, the higher abundance area in each habitat was demarcated with 10 transects of $2 \mathrm{~m}$ wide and $25 \mathrm{~m}$ long (Crimea Pond), 10 transects of $2 \mathrm{~m}$ wide and $20 \mathrm{~m}$ long (El Abuelo wetland), and 15 transects of $2 \mathrm{~m}$ wide and $50 \mathrm{~m}$ long (Tominé Dam) using cloth pennants. Samplings were conducted across the entire area around the shore, where $M$. laterale was observed perching, including pastureland, shrubbery, and trees. Each individual observed was caught, marked if necessary, and its sex and recapture data were recorded. Then, it was released on the same site. The whole process lasted less than 1 minute (Palacino -Rodríguez \& Contreras-Sánchez, 2014).

A total of 2820 individuals were marked. The observations followed the focal animal temporal sampling technique (Altman, 1974). Each session occurred from 09:00 to 18:00 h Colombian time (COT, UTC-5), divided into periods of $15 \mathrm{~min}$ (per individual), in which the sequence and changes in behavior were observed and recorded. During each 15-min period, environmental temperature was averaged from measurements recorded each 5 min using a digital thermohygrometer Anayco HTC-2 (Medellín, Antioquia, Colombia); 15 min later, a different marked animal was observed. We sorted our observations into the categories in Table 2. 
Table 2. Categories and subcategories for observations of M. laterale behavior.

\begin{tabular}{|c|c|}
\hline Category & Subcategory \\
\hline \multirow[t]{4}{*}{ Perching time in type of perch } & Grass \\
\hline & Trees \\
\hline & Garbage \\
\hline & Ground or rocks \\
\hline \multirow[t]{3}{*}{ Perch height } & Low: 0-20 cm \\
\hline & Medium: $20.1-50 \mathrm{~cm}$ \\
\hline & High: $\geq 50.1 \mathrm{~cm}$ \\
\hline \multicolumn{2}{|l|}{ Time spent foraging and feeding on prey } \\
\hline \multicolumn{2}{|l|}{ Time spent consuming $M$. laterale specimens by the predator } \\
\hline \multirow[t]{7}{*}{ Intraspecific aggressive interactions } & Male-male interactions \\
\hline & ${ }^{\mathrm{a}}$ mature male-mature male \\
\hline & ${ }^{\mathrm{b}}$ mature male-immature male \\
\hline & Male-female interactions \\
\hline & ${ }^{\mathrm{c}}$ mature male-immature female (mating type one, $\mathrm{M} 1$ ) \\
\hline & ${ }^{d}$ immature male-mature female (mating type two, M2) \\
\hline & ${ }^{\mathrm{e}}$ mature male and female (mating type three, M3) \\
\hline \multicolumn{2}{|l|}{ Interspecific aggressive interaction } \\
\hline \multicolumn{2}{|l|}{ Courtship behavior } \\
\hline \multicolumn{2}{|l|}{ Oviposition behavior } \\
\hline \multicolumn{2}{|l|}{ Mate guarding behavior } \\
\hline \multicolumn{2}{|l|}{ Mating behavior } \\
\hline Tandem linkage & \\
\hline
\end{tabular}

${ }^{\mathrm{a} B o t h}$ of the males had black color on dorsum of abdominal segments (S) 2 and 3

${ }^{\mathrm{b}}$ Male with black color on dorsum S2-3 and male with orange color on dorsum S2-3

${ }^{\mathrm{c}}$ Male with black color on dorsum S2-3 and female with orange color on dorsum S2-3

${ }^{\mathrm{d}}$ Male with orange color on dorsum S2-3 and female with black color on dorsum S2-3

${ }^{\mathrm{e}}$ Male and female with black color on dorsum S2-3

Searching for courtship behavior, we watched for signals as movements, evidence of flight or exhibition of corporal areas that would indicate to us whether females or males required those signal for subsequent mating. Oviposition occurred when eggs were deposited by a damselfly female, inserting them into aquatic plants. We wanted to record their mate's guarding behavior after oviposition, observing whether a male stayed in contact or whether it kept a close distance from his recent female mate. Tandem linkage occurred as part of reproductive behavior of damselflies when the male grasped the female by the neck with his terminal appendages, either as preparation for copulation or to protect a female with which he has copulated or will copulate.

We also included observations on interspecific behaviors of co-occurring species. We classified these observations into the following categories: (i) siege on $M$. laterale or other species; (ii) time when $M$. laterale and co-occurring species were simultaneously observed; (iii) height at which co-occurring species were simultaneously on the same perch area as M.laterale; and (iv) distance from water body shore to the perch location of $M$. laterale. To measure the height of the perch for pastureland, we used fiberglass measuring tapes $S_{K C}{ }^{\circledR} 150 \mathrm{~cm}$ long and $1.5 \mathrm{~cm}$ wide attached to a wooden table of $170 \mathrm{~cm}$ long $\times 3 \mathrm{~cm}$ wide as reference. Wooden tables were buried each $5 \mathrm{~m}$ inside of every transect for each location. To measure the height of the perch for tree branches, we used a distance meter RZ-T100 ${ }^{\mathrm{TM}}$ (Nanshan District, Shenzhen, China) in full mode option, which uses a Pythagorean proposition measurement function to measure height at trees. To avoid influencing adult behavior, observations were made from a distance of $2 \mathrm{~m}$ from the individual location, without making sudden movements or loud sounds. To collect data from our observations of tree branches, we used $10 \times 50 \mathrm{JHOPT}^{\mathrm{TM}}$ binoculars (Brighton, CO, USA). A data matrix of the observations including habitat, date, code number of the animal, sex of each individual, time, temperature, duration, and description for each activity was designed. 


\section{Environmental variables}

\section{Forest cover}

Forest cover was measured from the shore of a body of water up to $400 \mathrm{~m}^{2}$ away, where, depending on the habitat, a higher density of trees was seen or where some trees were present. We established three transects from the shore of the body of water up to $20 \mathrm{~m}$ away. In each transect, were placed points at 0,10 and $20 \mathrm{~m}$. In each point (nine points in total), we measured the percentage of forest cover. The forest cover was estimated using the amount of light penetrating the canopy, measured with a luxmeter Dr. Meter ${ }^{\mathrm{TM}}$ LX1330B (Hong Kong, China) (Lemmon, 1956) to establish the percentage of canopy cover (Table 1). The forest cover was expressed as the average of the measures taken in each habitat.

\section{Perch area}

We measured the longitude of area covered by vegetation from the shore of the body of water to the sites where we observed that $M$. laterale individuals were perching. The area was measured using a decameter 33332.17 L \& W Tools ${ }^{\mathrm{TM}}$ (Furong District, Changsha, Hunan, China). For the Crimea Pond, the area measured was $20 \mathrm{~m}$ from the shore $\times 25 \mathrm{~m}$ off the shore (a total area of $500 \mathrm{~m}^{2}$ ). For El Abuelo wetland, the area was $20 \mathrm{~m}$ from the shore $\times 20 \mathrm{~m}$ off the shore (a total area of $400 \mathrm{~m}^{2}$ ), and around the Tominé Dam, the area was $30 \mathrm{~m}$ from the shore $\times 50 \mathrm{~m}$ off the shore (a total area of $1500 \mathrm{~m}^{2}$ ).

\section{Percentage of macrophytes}

The percentage of macrophytes on the water surface was estimated using a densitometer IHAC-T5 ${ }^{\mathrm{TM}}$ (Arlington, VA, USA). We assumed that the total area in the body of water was $100 \%$ and estimated how much of that percentage was covered by macrophytes. We measured 20 points in each habitat, and the percentage of macrophytes on the water surface was expressed as the average of the measurements taken in each habitat.

\section{Statistical analysis steps}

To meet our first objective, i.e. observe daily abundance of individuals near of waterbodies, we developed the following steps:

- Step 1: Probability of resight was obtained by dividing the number of recaptured individuals into the total number of marked individuals.

- Step 2: The results of the probability of resight (Table 1) were analyzed using $\mathrm{Chi}^{2}$ tests with SPSS (IBM ${ }^{\mathrm{TM}}$ Inc., Armonk, NY, USA) for males and females by location, and only males or only females in every location.

- Step 3: Highest reproductive activity was determined with a circular analysis of daily abundance at the breeding site, obtaining a maximum activity vector for each sex and for both sexes in each stream using Oriana 3.0 (RockWare ${ }^{\mathrm{TM}}$ Inc., Golden, CO, USA).

- Step 4: Uniformity of circular data was assessed, using a Rao's spacing t-test.

For our objectives (ii) and (iii), i.e. to observe (ii) differences in the type and frequency of the behavior (reproductive and non-reproductive) by location and (iii) differences between time used to perch in different types of perch, a Kruskal-Wallis test was used (Step 5). 
For objective (iv), i.e. to observe possible relationships between time used to perch and the environment temperature by habitats, Spearman's rank-order correlation was used (Step 6).

\section{Results}

\section{Daily abundance}

Mesamphiagrion laterale was most active at 12:13 hours $(p<0.01$; Figures 3-5) on the three locations. This analysis was conducted separately for each sex but was not statistically significant [males, 12:14 hours $(p<0.01)$, Figures 3c, 4c, 5c; females, 12:13 hours $(p<0.01)$; Figures $3 b, 4 b, 5 b]$. During the rainy season, this species was most active at 12:13 hours $(p<0.01$; Figure $4 \mathrm{a}-\mathrm{c}$ ), and there were no differences between sex (female, 12:15 hours, Figure 4b; male, 12:13 hours, Figure 4c). During the dry season, damselflies were most active at 12:19 hours $(p<0.01$; Figure $5 \mathrm{a}-\mathrm{c})$, and in this season, periods of higher activity were observed before in
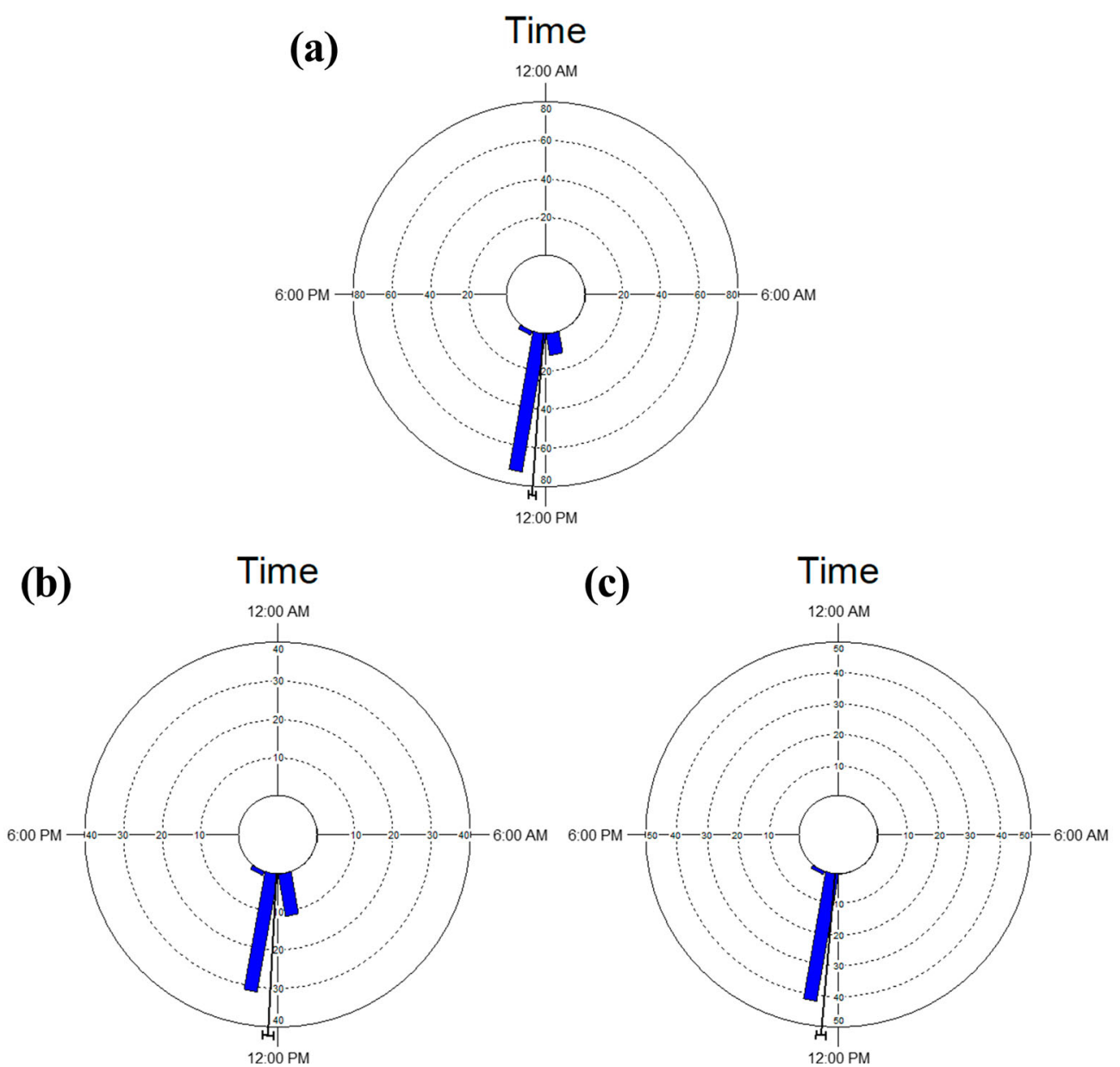

Figure 3. Overall daily abundance range of Mesamphiagrion laterale individuals for (a) both sexes, (b) females, and (c) males. The arrow indicates the mean abundance vector. The bars indicate the number of individuals; the sum of these values is specified in Supplemental material 1. 

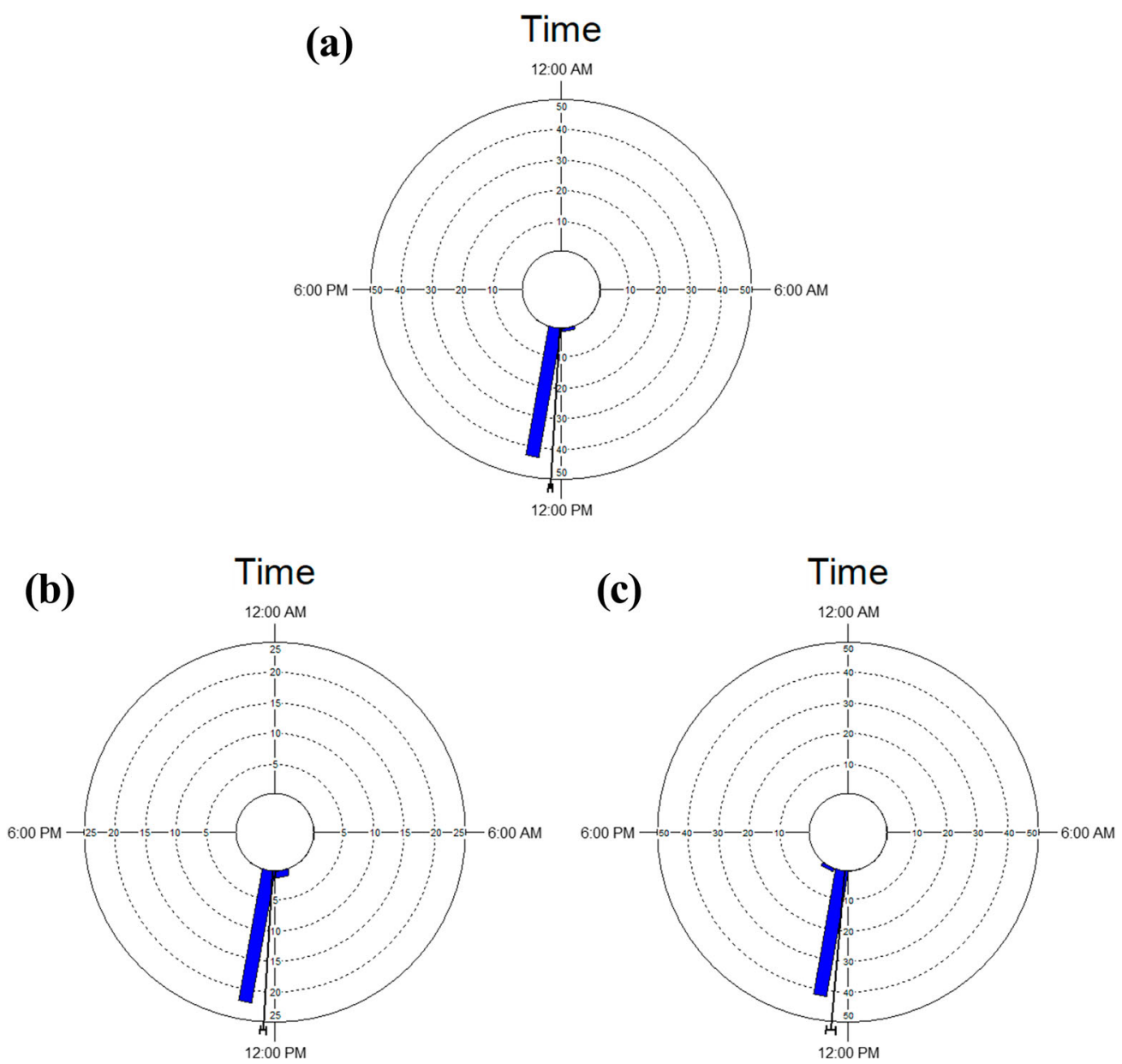

Figure 4. Daily abundance range of Mesamphiagrion laterale during the rainy season for (a) both sexes, (b) females, and (c) males. The arrow indicates the mean abundance vector. The bars indicate the number of individuals; the sum of these values is specified in Supplemental material 1.

females than in males [female, 12:00 hours $(p<0.01)$, Figure 5b; male, 12:35 hours $(p<0.01)$, Figure 5c].

\section{Type and frequency of behavior}

\section{Perch behavior}

Mesamphiagrion laterale males were three times as abundant as females. No significant difference between sexes was found in the probability of resight at each location, or by sex comparing all locations (Table 1). M. laterale perches were observed on grass and other shore-related herbs. Other perches included tree branches, garbage (e.g. bottles, plastic bags, diapers, and buckets) inside or outside the water, rocks, or directly on the ground. Our analyses indicate a significant difference between the times spent on each perch type within and between locations $(p<0.001$; Table 3). Most of the time, they were observed perching on grass, followed by tree branches, trash, and at a lower rate, directly on the ground and rocks (Table 4). Moreover, time spent perching was highest at Tominé Dam (Supplemental Material 1), followed by El Abuelo Wetland 

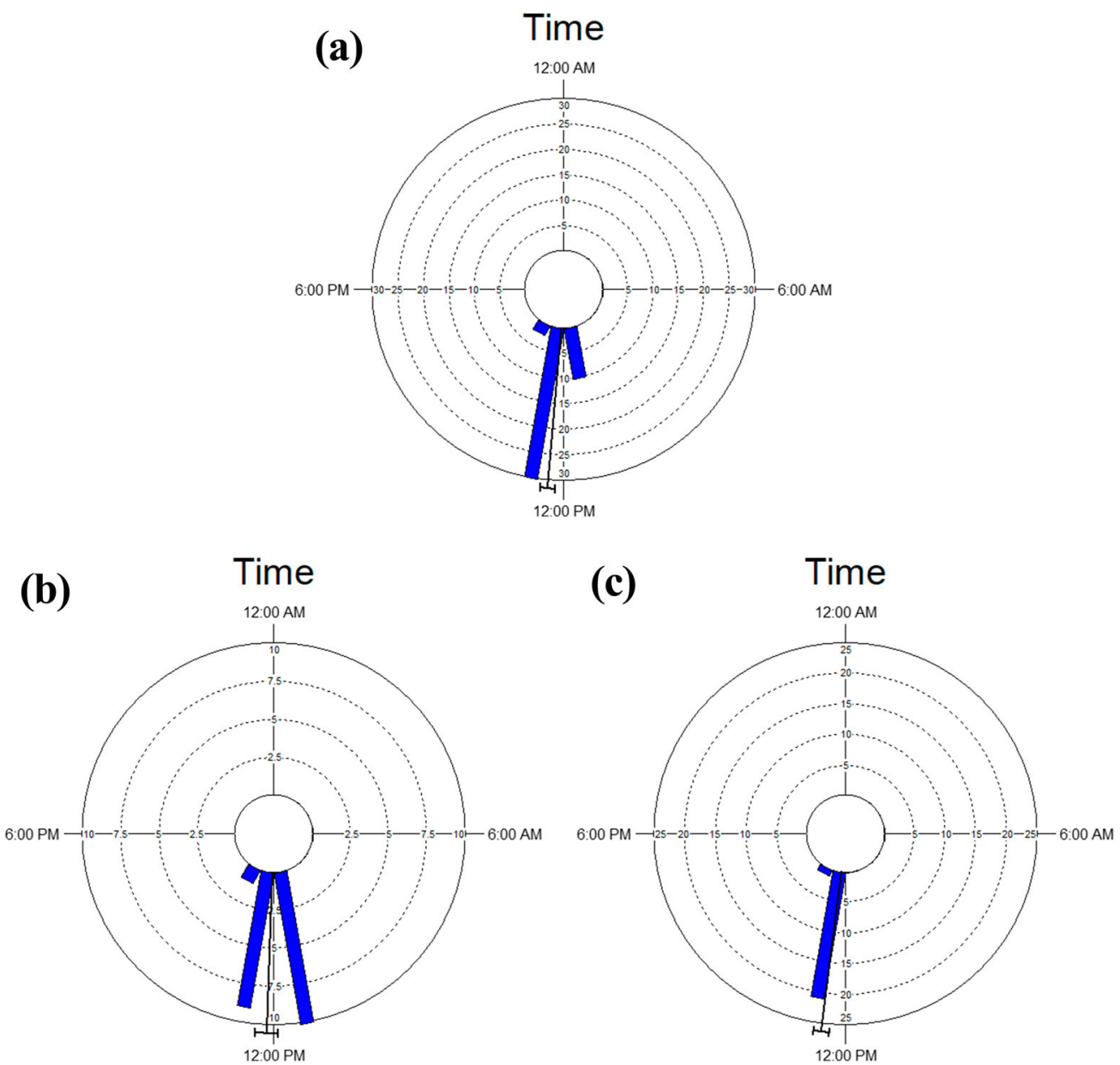

Figure 5. Daily abundance ranges of Mesamphiagrion laterale during the dry season for (a) both sexes, (b) females, and (c) males. The arrow indicates the mean abundance vector. The bars indicate the number of individuals; the sum of these values is specified in Supplemental material 1.

Table 3. Statistical evaluation in time spent perching by habitats and correlation between time spent perching and temperature by habitats.

\begin{tabular}{llcr}
\hline Statistic & \multicolumn{1}{c}{ Habitat } & $p$-value & $r$-value \\
\hline \multirow{2}{*}{ Kruskal-Wallis test } & Agricultural well by Crimea Pond & $6.69 \mathrm{E}-09$ & \\
& Reservoir by Tominé dam & $6.63 \mathrm{E}-22$ & \\
& Fishing lake by El Abuelo wetland & $3.12 \mathrm{E}-28$ & \\
& Among habitats & $5.20 \mathrm{E}-67$ & \\
Spearman's correlation & Agricultural well by Crimea Pond & 0.11 & 0.04 \\
& Reservoir by Tominé dam & 0.61 & -0.01 \\
& Fishing lake by El Abuelo wetland & 0.45 & 0.02 \\
\hline
\end{tabular}

(Supplemental Material 2) and Crimea Pond (Supplemental Material 3). Relationship between temperature and amount of time spent perching or perching site was not significant (Table 3 ).

During perching, $M$. laterale individuals adopted one of the following three positions: (i) horizontal position and perpendicular to the longitudinal axis of the branch $(6.3 \%$, Figure $6 a)$; (ii) 
Table 4. Number of events by perch position.

\begin{tabular}{|c|c|c|c|c|c|c|c|c|c|}
\hline & \multicolumn{3}{|c|}{ Crimea } & \multicolumn{3}{|c|}{ El Abuelo } & \multicolumn{3}{|c|}{ Tominé } \\
\hline & $\mathrm{H}$ & $\mathrm{P}$ & $\mathrm{D}$ & $\mathrm{H}$ & $\mathrm{P}$ & $\mathrm{D}$ & $\mathrm{H}$ & $\mathrm{P}$ & $\mathrm{D}$ \\
\hline Grass & 34 & 65 & 806 & 27 & 45 & 859 & 38 & 65 & 881 \\
\hline Trees & 21 & 89 & 346 & 23 & 41 & 167 & 23 & 24 & 256 \\
\hline Garbage & 9 & 3 & 4 & 4 & 2 & 1 & 25 & 16 & 17 \\
\hline Ground & 9 & 3 & 3 & 21 & 8 & 5 & 15 & 4 & 2 \\
\hline Total by perch & 73 & 160 & 1159 & 75 & 96 & 1032 & 101 & 109 & 1156 \\
\hline Total by locality & \multicolumn{3}{|c|}{1392} & \multicolumn{3}{|c|}{1203} & \multicolumn{3}{|c|}{1366} \\
\hline
\end{tabular}

Notes: $\mathrm{H}$ - Horizontal position in perch; $\mathrm{P}$ - Parallel position in perch; and D - Diagonal position in perch.

parallel position to the branch $(9.2 \%$, Figure $6 \mathrm{~b})$, which was particularly adopted by teneral individuals or adults at temperatures $\leq 6^{\circ} \mathrm{C}$; and (iii) diagonal position $(84.5 \%$, Figure $6 \mathrm{c})$. Two to seven individuals were observed on the same perch, demonstrating an intraspecific behavior referred to by us as "waiting in line". We observed that, upon landing on an empty perch, the damselfly walked up toward the apex and occupied that place. The damselflies that arrived later only walked up to the location behind the first damselfly and occupied that place. Once the damselfly at the apex left the perch, the other damselflies walked up toward the apex where the damselfly that was originally on the second place now occupied the apex (Figure 7).

Both males and females were observed among kikuyu (Pennisetum clandestinum) grass within the perching area, whereas females were occasionally observed in densely vegetated areas among Acacia sp. tree branches. Even though the relationship between temperature and amount of time spent perching or perching site was not significant (Table 3), we found that, during times of high temperature, sexually immature females (juvenile) were primarily observed among grass. During rainy days or after 16:00 hours, when the temperatures dropped, the damselflies took shelter at the base of the grass shoots, which rendered them less visible.

\section{Foraging behavior}

A total of 149 foraging events (Supplemental Material 1-3) were observed on cicadelids (90), mosquitoes (38), spiders (12), and other odonates as Ischnura chingaza Realpe, 2010 (five individuals) and Ischnura cruzi DeMarmels, 1987 (four individuals). The time spent consuming these types of prey ranged between 2 and $15 \mathrm{~min}$; the latter time was spent for bigger prey, primarily from $11: 30$ to $14: 00$ hours when the temperature surpassed $12^{\circ} \mathrm{C}$. On the other hand, 98 events were recorded wherein $M$. laterale was preyed upon. The predators included Larinia sp. spiders (Arachnida: Araneae; 93 events) and the bird Zonotrichia capensis (Müller, 1776) (Passeriformes: Emberizidae; five events). The time spent hunting and consuming M. laterale ranged between 5 and 15 min. However, we observed 15 damselflies getting caught on spider nets and freeing themselves by moving their abdomen. Predation upon $M$. laterale occurred at temperatures above $6^{\circ} \mathrm{C}$ at any time of the day. Between seasons, the recorded temperature ranges for the different behaviors were similar for all locations. The duration of each behavior varied between locations, and the amount of time spent for these behaviors was lower during the rainy season in all locations (Supplemental Material 1-3).

\section{Reproductive behavior}

Although males showed higher fidelity to vegetation closer to the water and we recorded no territorial behavior in this species, intra- and interspecific interactions frequently occurred. The 
(a)

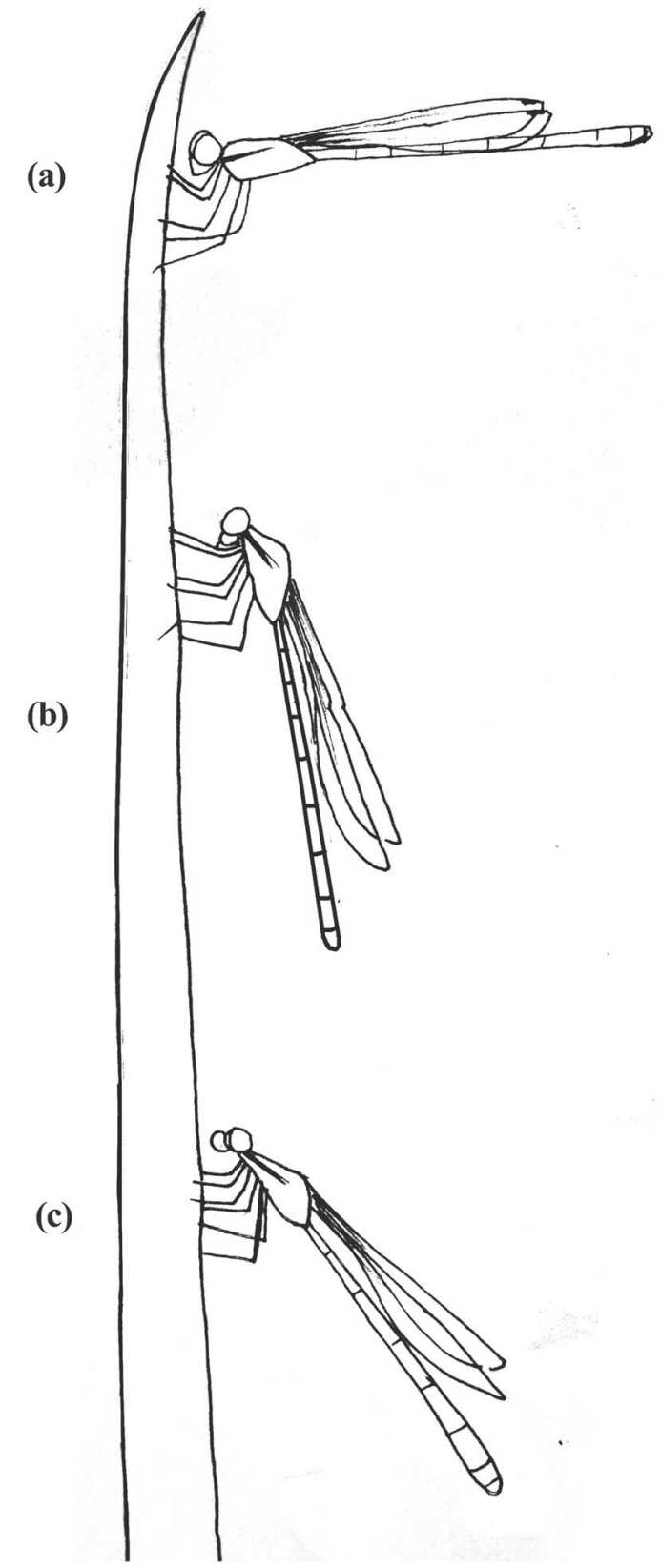

Figure 6. Perching positions of Mesamphiagrion laterale. (a) horizontal position, (b) parallel position, and (c) diagonal position. Illustration: P. Camacho.

intraspecific interactions (643 records) mainly consisted of males attacking other males, females, pairs in tandem, or copulating pairs. Around 1-5 males were observed simultaneously attacking pairs.

We observed no clear courtship behavior in this species. Pairs in tandem were observed between 10:00 and 15:00 h, during temperatures between $15^{\circ} \mathrm{C}$ and $25^{\circ} \mathrm{C}$, and tandem lasted for 3 to 90 min (100\% or 155 observed events). During this time, the male gripped the female 

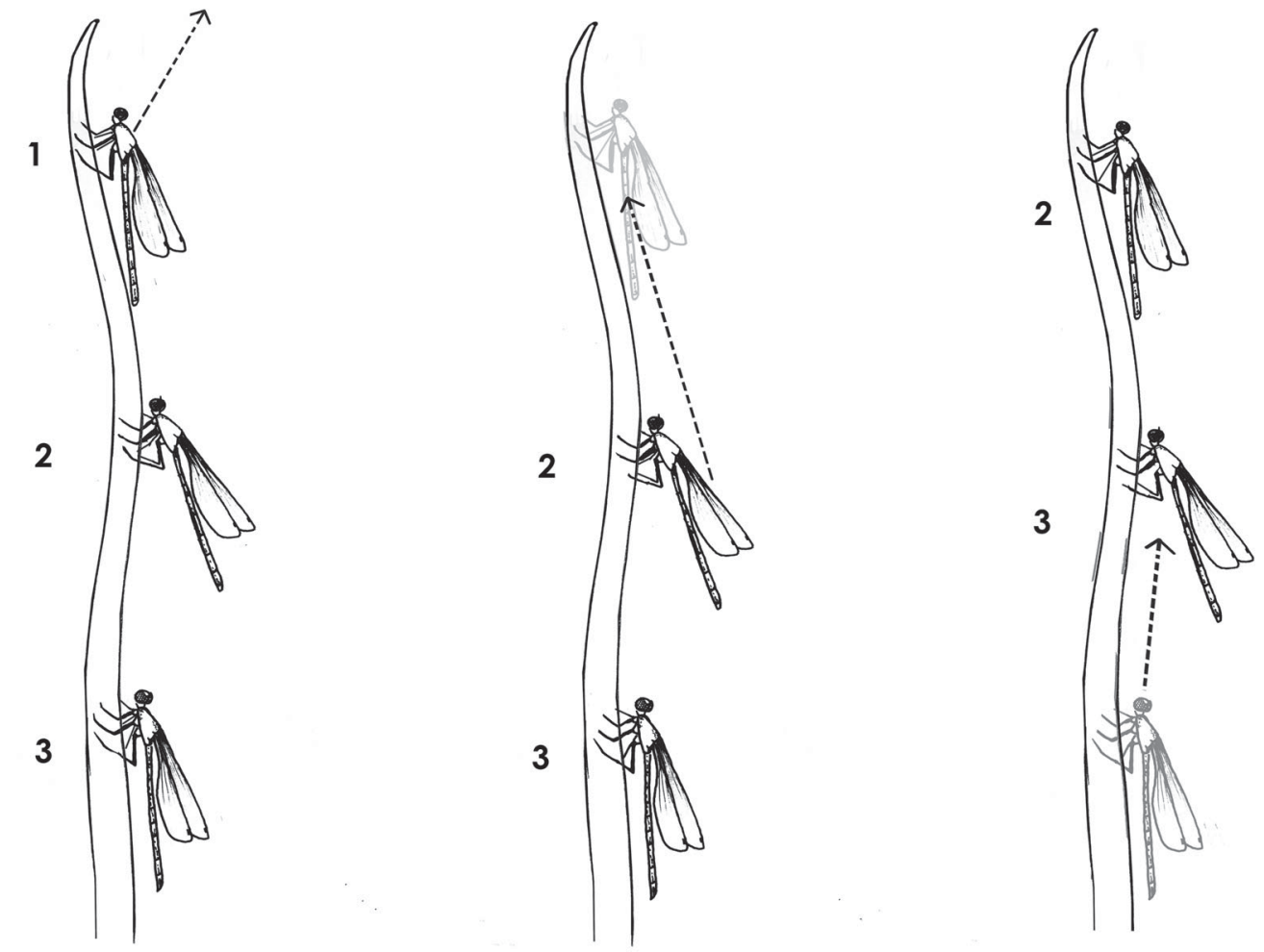

Figure 7. Mesamphiagrion laterale damselflies "waiting in line". Once the damselfly perched on the apex leaves the perch (1), the other two damselflies (2 and 3) move up the perch to occupy a higher position on the perch. Illustration: P. Camacho.

by the thorax (100\% of observed events) and repeatedly moved his abdomen (100\% of observed events). With these abdominal movements, the male touched the ventral region of their second segment with the last segments of the female in an attempt to adopt a wheel formation with a receptive female (100\% of observed events). If the female was not receptive $(93.5 \%$ of observed events), the male tried again until the female either became receptive $(6.5 \%$ of observed events) or freed herself from the male's grip (93.5\% of observed events). The male transported the female over several minutes to different perches, taking breaks between perches (100\% of observed events). During the non-flight time intervals of the tandem, the females rested their abdomen against the perches, further obstructing copulation (80\% of observed events).

We recorded three tandem alternative male-female interactions: mature male-immature female (36 pairs, 18\%), immature male-mature female (8 pairs, 4\%), and male and female mature (155 pairs, 78\%). Copulation lasted 7-15 minutes (SD; Supplemental Material 1-3) and site selection included: (i) selection of a landing site (Waage, 1987); (ii) choice of the insertion site; and (iii) deposition of eggs (Martens, 2001). During oviposition, the female was observed submerging the last abdominal segments, the entire abdomen, or even the abdomen and the thorax in the mud underneath E. crassipes shoots. Oviposition lasted 12-15 min (SD; Supplemental Material 1-3), during which the females constantly moved their abdomen back and forth. Occasionally, some females also performed these movements on emerged portions of the 


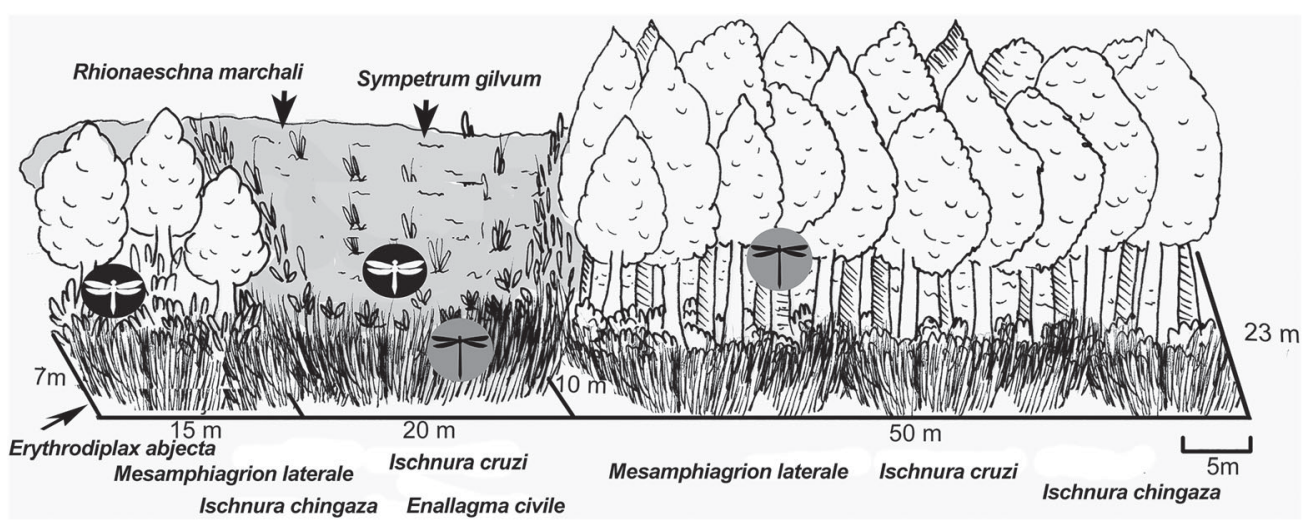

Figure 8. Habitat spatial partitioning of Odonata species in habitats from the Colombian Andes. Illustration: P. Camacho.

plant. Oviposition took place both with the presence and absence of the male (even underwater). The temperatures during the reproductive behavior ranged between $15^{\circ} \mathrm{C}$ and $25^{\circ} \mathrm{C}(\mathrm{SD}$; Supplemental Material 1-3).

\section{Interspecific interactions}

The number of attacks (average of 2.3 attacks) on M. laterale was highest by Sympetrum gilvum (Selys, 1884), and Erythrodiplax abjecta (Rambur, 1842) males attacked M. laterale at least once. These interactions lasted for 5-20 s. Sympetrum gilvum, E. abjecta, and Enallagma civile (Hagen, 1861) frequented the studied habitats for only 2-3 h around noon. Erythodiplax abjecta and I. chingaza appeared at around 10:00 hours and stayed until the night. E. abjecta showed a similar habitat use pattern to that of M. laterale. S. gilvum, Rhionaeschna marchali (Rambur, 1842), E. abjecta, and E. civile occupy different areas to the other species (Figure 8). Sympetrum gilvum and $R$. marchali preferred the highest perches, whereas E. civile preferred lower perches, and the rest of the species perched on the middle ground. Sympetrum gilvum frequently perched on perches close to the water frequently used by $M$. laterale. In comparison to $M$. laterale, a higher percentage of $R$. marchali used perches farther away from the water, whereas the rest of the species used perches at comparable distances (Supplemental Material 4).

\section{Discussion}

\section{Daily abundance}

Our results showed that daily abundance was more intense around 12:13 hours without differences between sexes. However, at early midday, the females, during the dry season, have a larger number of individuals on the breeding site at 12:13 hours. Odonata activity is known to depend on the environmental temperature and the ability to regulate body temperature (DeMarco \& Resende, 2002; Lambret \& Stoquert, 2011). At 12:13 hours, the locations under study have the highest temperatures during the day ( $\geq 20^{\circ} \mathrm{C}$, IDEAM, 2017). Thus, during midday and dry season, the daily abundance of $M$. laterale individuals increases because of the amount of sunlight 
available that makes possible that individuals visit aquatic sites in order to mate and lay their eggs (Esquivel, 2006).

\section{Type and frequency of behavior}

\section{Perch behavior}

Even though this species is not territorial, its perching behavior suggests its affinity to the water body, since most individuals were observed perching on the same site. In our study, male-male interactions show similarities to those of other members of the Coenagrionidae reported in other studies (e.g. Ischnura and Acanthagrion), including short chases and fights (Guillermo-Ferreira \& Del-Claro, 2012; Robertson, 1985; Sirot \& Brockmann, 2001). For M. laterale, the most common perches were medium-height grass close to the water, probably associated with the chance of capturing prey and thermoregulation (not measured by us). The latter could be an important factor, especially considering the constant seasonal temperature oscillations (rainy and dry seasons) and the time of the day (IDEAM, 2017). The thermo-conformist M. laterale responds to these factors by changing its location on the perch and not perch height, although during rainy days or after 16:00 hours, when the temperatures dropped, the damselflies took shelter at the base of the grass shoots, which rendered them less visible.

\section{Foraging behavior}

The wide variation in food consumed by $M$. laterale matched the generalist feeding characteristics of odonates (Chari, Moyo, \& Richoux, 2018; Corbet, 1999). Although we did not measure predation for co-occurring species, we saw that $M$. laterale dominated areas in the perch area that are abundant with particular species of prey such as small mosquitoes and cicadelids. In the areas where those prey are not common, there are other prey that are more abundant. Thus, we believe that it is possible that prey can regulate the dispersion of $M$. laterale and the coexistence of large and small odonate co-occurring species in the studied locations (Baltensperger, Huettmann, Hagelin, \& Welker, 2015), but more research is required in order for this to be verified.

\section{Reproductive behavior}

A relationship between prolonged copulation and non-territorial condition has been shown by several zygopterans, which use prolonged copulation time to prevent sperm competition (e.g. Ischnura; Cordero-Rivera, 1990). In M. laterale, no territoriality was perceived and extended periods of copulation may be present ( 15 or more minutes). Furthermore, males contact guarding while in tandem during oviposition (Cordero-Rivera, 1990 and references therein). However, it is not clear whether this behavior is to prevent sperm competition because it was not measured in this study.

During $M$. laterale tandem, males signal their reproductive readiness, whereas females reject the male when they are apparently not sexually receptive, which obstructs copulation and results in the male releasing the female. For other Odonata species, there have been records of persistent males holding their grip on females for long periods of time until the female becomes receptive (Fincke, 1997). We found that M. laterale males are highly persistent (up to $90 \mathrm{~min}$ ) and continuously move their abdomen (touching their abdominal segment 2 on the female's last segments) in an attempt to possibly transfer sperm and to signal reproductive readiness to the female. Nevertheless, several tandems lasted for long periods of time, with several unsuccessful attempts of 
the male to copulate, which could suggest that this persistent behavior is a result of the males' and females' inability to recognize unreceptive signals such as those suggested for other Odonata species (Fincke, 1997). Longer periods of time were recorded for mature individuals (male and female) and not in mature and immature individuals, suggesting that prolonged tandem is not held on for maturation of immature females.

In $M$. laterale, copulation took place over short periods of time (7-15 min), making the females' receptiveness windows short and reducing the chance that males have to receive and interpret the females' signals. Considering that we have not observed any type of such receptiveness signals from females, it is possible that this species lacks such reproductive signals and that females only copulate with males to avoid being attacked by the males, which are three times more abundant than females (Clutton-Brock, Price, \& MacColl, 1992; Rowe, Arnqvist, Sih, \& Krupa, 1994).

The reproductive behavior pattern observed in M. laterale includes aspects reported for other Coenagrionids, with regard to monogamy improving female fitness (Rowe, 1978; Fincke, 1987; Robinson \& Allgeyer, 1996). Additional pieces of evidence supporting this include fewer copulations (4.32\% of the observed M. laterale, see also Parr and Palmer, 1971; Robinson \& Allgeyer, 1996), as well as tandems between mature males and immature females (18\% in this study; see also Rowe, 1978). These events occurred more often in the dam habitat, which is characterized by a larger perching area close to the water, and by a more extensive forest cover, which prevents the microhabitat's temperature from increasing. Nevertheless, $M$. laterale, like other zygopterans, prefers quiet sites with high diversity of plants, clearer water and with a lower probability of being attacked by conspecifics (Martens, 1992, 1993, 1994).

\section{Interspecific interactions}

To avoid competitive exclusion, co-occurring species exploited resources through niche partitioning (Siepielski \& McPeek, 2010). As with other odonates, species interactions within this community could be explained by two types of niche partitioning: temporal (DeMarco \& Resende, 2002; Samways, Caldwell, \& Osborn, 1996) and spatial (Osborn \& Samways, 1996; Raab, Chovanec, \& Wiener, 1996; Reinhardt, 1999). Even though the temperature might seem to explain the presence or absence of certain species, the thermo-conformist nature of $M$. laterale suggests that temperature might not be the most important factor for every species. Undoubtedly, the temperatures at which $S$. gilvum and $R$. marchali were observed enabled them to be more active and display reproductive and foraging behaviors, which they would not be able to perform at lower temperatures.

Spatial partitioning included several sites within the habitat (Figure 8) and different perching locations. Following the traditional niche theory, the main factor leading to interspecific competition is the similarity of resources exploited by different species. Thus, two or more species will compete more strongly for a niche if they occur in the same environment and have similar requirements (Duyck, David, \& Quilici, 2004). This behavior was evident between Ischnura spp. and M. laterale, which occurred more frequently in grass patches close to the water (within 1-5 m), wherein M. laterale was most abundant (40:1) and displaced Ischnura spp. from their perches. Interspecific competition is common among insects (Reitz \& Trumble, 2002; Stewart, 1996) and takes place through a mechanism referred to as competitive displacement, i.e., the elimination of one species from a habitat or part thereof by a superior or stronger species (DeBach, 1966).

Several factors lead to interference competition displacement (Reitz \& Trumble, 2002), including the differential impact of natural enemies and local adaptations. As far as natural enemies are concerned, in these habitats we observed that smaller damselflies (Ischnura spp. and M. laterale) 
are more susceptible to predators (i.e. spiders, birds, and other odonates). Local adaptations are particularly evident for S. gilvum and R. marchali, which occupy areas that are more restricted within the water area. The habitat zones dominated by E. abjecta (Figure 8 ) are characterized by dry grasslands due to acidification resulting from Eucalyptus sp. Thus, we could assume that E. abjecta uses its color to camouflage with the grassland, but more studies will be done to complete our findings.

\section{Acknowledgements}

We are grateful to Paola Camacho for providing the beautiful illustrations and Mauren Silva for the photo. We thank Grupo de Investigación en Odonatos y otros artrópodos de Colombia (GINOCO), Grupo de Investigación en Biología (GRIB) of the Biology Department at Universidad El Bosque, and the Centro de Investigación en Acarología. We thank Vicerrectoría de Investigaciones of the Universidad El Bosque for the support in the process of revision and improvement of the previous version of this paper. This research did not receive any specific grant from funding agencies in the public, commercial, or not-for-profit sectors.

\section{Supplemental materials}

Supplemental data for this article can be accessed at https://doi.org/10.1080/13887890.2020.1739567.

\section{References}

Altamiranda-Saavedra, M., Palacino-Rodríguez, F., \& Lobo-Hernández, M. (2014). Daily abundance at the breeding site and reproductive behavior of Polythore gigantea (Odonata: Polythoridae). Odonatologica, 43, 169-182.

Altmann, J. (1974). Observational study of behavior: sampling methods. Behaviour, 49, 227-267. doi:10.1163/15685397 $4 \mathrm{X} 00534$.

Álvarez-Covelli, C., Álvarez-Covelli, M. A., \& Palacino-Rodríguez, F. (2015). Abdomen or wings? Comparing two body places for marking in Mesamphiagrion laterale (Odonata: Coenagrionidae). Odonatologica, 44, 343-348.

Alves-Martins, F., Del-Claro, K., \& Jacobucci, G. B. (2012). Sexual size dimorphism, mating system and seasonality of a Neotropical damselfly, Telebasis carmesina (Coenagrionidae). International Journal of Odonatology, 15, $263-273$. doi:10.1080/13887890.2012.719422.

Baird, J. M., \& May, M. L. (1997). Foraging behavior of Pachydiplax longipennis (Odonata: Libellulidae). Journal of Insect Behavior, 10, 655-678. doi:10.1007/BF02765385.

Baltensperger, A. P., Huettmann, F., Hagelin, J. C., \& Welker, J. M. (2015). Quantifying trophic niche spaces of small mammals using stable isotopes $(\delta 15 \mathrm{~N}$ and $\delta 13 \mathrm{C}, \delta 15 \mathrm{~N})$ at two scales across Alaska. Canadian Journal of Zoology, 93, 579-588. doi:10.1139/cjz-2015-0025

Bota-Sierra, C., \& Wolff, M. (2013). Taxonomic revision of Mesamphiagrion Kennedy, 1920 from Colombia (Odonata: Coenagrionidae), with the description of four new species. Zootaxa, 3718, 401-440. http://doi.org/ 10.11646/zootaxa.3718.5.1

Chapin, F. S., III, Matson, P. A., \& Vitousek, P. M. (2011). Principles of terrestrial ecosystem ecology. New York, USA: Springer-Verlag, 529p.

Chari, L. D., Moyo, S., \& Richoux, N. B. (2018). Trophic ecology of adult male Odonata. I. Dietary niche metrics by foraging guild, species, body size, and location. Ecological Entomology, 43, 1-14. https://doi.org/10.1111/een.12458

Clutton-Brock, T. H., Price, O. F., \& MacColl, A. D. C. (1992). Mate retention, harassment, and the evolution of ungulate leks. Behavioral Ecology, 3, 234-242. doi:10.1093/beheco/3.3.234.

Corbet, P. (1999). Dragonflies: Behaviour and ecology of Odonata. Colchester, UK: Harley Books, 882p.

Corbet, P. S., \& May, M. L. (2008). Fliers and perchers among Odonata: dichotomy or multidimensional continuum? A provisional reappraisal. International Journal of Odonatology, 11, 155-171. doi:10.1080/13887890.2008.9748320.

Cordero-Rivera, A. (1990). The adaptive significance of the prolonged copulations of the damselfly, Ischnura graellsii (Odonata: Coenagrionidae). Animal Behavior, 40, 43-48. doi:10.1016/S0003-3472(05)80664-5.

Cordero-Rivera, A., \& Stoks, R. (2008). Mark-recapture studies and demography. In A. Córdoba-Aguilar (Ed.), Dragonflies and damselflies: Model organisms for ecological and evolutionary research (pp. 7-20). Oxford, Oxford University Press.

Córdoba-Aguilar, A., Serrano-Meneses, M. A., \& Cordero-Rivera, A. (2009). Copulation duration in nonterritorial odonate species lasts longer than in territorial species. Annals of the Entomological Society of America, 102, 694-701. https://doi.org/10.1603/008.102.0414.

DeBach, P. (1966). The competitive displacement and coexistence principles. Annual Review of Entomology, 11, 183-212. doi:10.1146/annurev.en.11.010166.001151.

DeMarco Jr, P., \& Resende, D. C. (2002). Activity patterns and thermoregulation in a tropical dragonfly assemblage. Odonatologica, 31, 129-138. 
De Marmels, J. (1988). Odonata del Estado Táchira. Revista Científica UNET, 2, 91-111.

De Marmels, J. (1997). New and little-known species of Cyanallagma Kennedy, 1920 from the Andes and from Pantepui (Zygoptera: Coenagrionidae). Odonatologica, 26, 135-157.

Duyck, P. F., David, P., \& Quilici, S. (2004). A review of relationships between interspecific competition and invasions in fruit flies (Diptera: Tephritidae). Ecological Entomology, 29, 511-520. doi:10.1111/j.0307-6946.2004.00638.x.

Esquivel, C. (2006). Dragonflies and damselflies of Middle America and the Caribbean. Santo Domingo de Heredia, Costa Rica: Instituto Nacional de Biodiversidad. (INBIO), 320 p.

Fincke, O. M. (1987). Female monogamy in the damselfly Ischnura verticalis Say (Zygoptera: Coenagrionidae). Odonatologica, 16, 129-143.

Fincke, O. M. (1997). Conflict resolution in the Odonata: implications for understanding female mating patterns and female choice. Biological Journal of the Linnean Society, 60, 201-220. doi: 10.1111/j.1095-8312.1997.tb01492.x.

Gorb, S. N. (1994). Female perching behavior in Sympetrum sanguineum (Muller) at feeding places (Anisoptera: Libellulidae). Odonatologica, 23, 341-353.

Guillermo-Ferreira, R., \& Del-Claro, K. (2011). Oviposition site selection in Oxyagrion microstigma Selys, 1876 (Odonata: Coenagrionidae) is related to aquatic vegetation structure. International Journal of Odonatology, 14, 275-279. doi:10.1080/13887890.2011.621109.

Guillermo-Ferreira, R., \& Del-Claro, K. (2012). Reproductive behavior of Acanthagrion truncatum Selys, 1876 (Odonata: Coenagrionidae). International Journal of Odonatology, 15, 299-304. doi:10.1080/13887890.2012. 740596.

Instituto de Hidrología, Meteorología y Estudios Ambientales, IDEAM. (2017). Variabilidad diaria de temperatura. Retrieved from: http://www.ideam.gov.co/web/tiempo-y-clima/variabilidad-diaria-temperatura.

Lambret, P. H., \& Stoquert, A. (2011). Diel pattern of activity of Lestes macrostigma at a breeding site (Odonata: Lestidae). International Journal of Odonatology, 14, 175-191. doi:10.1080/13887890.2011.592134.

Lee, K. P., Simpson, S. J., \& Wilson, K. (2008). Dietary protein-quality influences melanization and immune function in an insect. Functional Ecology, 22, 1052-1061. https://doi.org/10.1111/j.1365-2435.2008.01459.x.

Lemmon, P. E. (1956). A spherical densiometer for estimating forest overstory density. Forest Science, 2, 314-320. https://doi.org/10.1093/forestscience/2.4.314.

Loiola, G. R., \& De Marco, P. (2011). Behavioral ecology of Heteragrion consors Hagen (Odonata, Megapodagrionidae): a shade-seek Atlantic forest damselfly. Revista Brasileira de Entomologia, 55, 373-380. doi:10.1590/ S0085-56262011005000036.

Martens, A. (1992). Egg deposition rates and duration of oviposition in Platycnemis pennipes (Pallas) (Insects: Odonata). Hydrobiologia, 230, 63-70.

Martens, A. (1993). Influence of conspecifics and plant structures on oviposition site selection in Pyrrhosoma nymphula (Sulzer) (Zygoptera: Coenagrionidae). Odonatologica, 22, 487-494.

Martens, A. (1994). Field experiments on aggregation behaviour and oviposition in Coenagrion puella (L.) (Zygoptera: Coenagrionidae). Advances in Odonatology, 6, 49-58.

Martens, A. (2001). Initial preference of oviposition sites: discrimination between living and dead plant material in Sympecma fusca and Coenagrion caerulescens (Odonata: Lestidae, Coenagrionidae). European Journal of Entomology, 98, 121-123. doi:10.14411/eje.2001.021.

May, M. L. (1976). Thermoregulation and adaptation to temperature in dragonflies (Odonata: Anisoptera). Ecological Monographs, 46, 1-32. doi:10.2307/1942392.

May, M. L. (1978). Thermal adaptations of dragonflies. Odonatologica, 7, $27-47$.

May, M. L. (1984). Energetics of adult Anisoptera, with special reference to feeding and reproductive behavior. Advances in Odonatology, 2, 95-116.

Osborn, R., \& Samways, M. J. (1996). Determinants of adult dragonfly assemblage patterns at new ponds in South Africa. Odonatologica, 25, 49-58.

Palacino-Rodríguez, F., \& Contreras-Sánchez, N. A. (2014). Does experimental marking of wings influence resighting success in Mesamphiagrion laterale and Erythrodiplax umbrata? (Odonata: Coenagrionidae, Libellulidae). Odonatologica, 43, 237-246.

Parr, M. J., \& Palmer, M. (1971). The sex ratios, mating frequencies and mating expectancies of three coenagriids (Odonata: Zygoptera) in Northern England. Insect Systematics \& Evolution, 2, 191-204. doi:10.1163/ 187631271 X00202.

Raab, R., Chovanec, A., \& Wiener, A. K. (1996). Aspects of habitat selection by adult dragonflies at a newly created pond in Vienna, Austria. Odonatologica, 25, 387-390.

Reinhardt, K. (1999). The reproductive activity of two Pseudagrion species in the same habitat (Odonata: Coenagrionidae). African Entomology, 7, 225-232.

Reitz, S. R., \& Trumble, J. T. (2002). Competitive displacement among insects and arachnids. Annual Review of Entomology, 47, 435-465. doi:10.1146/annurev.ento.47.091201.145227.

Robertson, H. M. (1985). Female dimorphism and mating behaviour in a damselfly, Ischnura ramburi: females mimicking males. Animal Behavior, 33, 805-809. doi:10.1016/S0003-3472(85)80013-0.

Robinson, J. V., \& Allgeyer, R. (1996). Covariation in life-history traits, demographics and behaviour in ischnuran damselflies: the evolution of monandry. Biological Journal of the Linnean Society, 58, 85-98. doi:10.1111/j.1095-8312.1996.tb01662.x.

Rosenzweig, M. L. (2001). Loss of speciation rate will impoverish future diversity. Proceedings of the National Academy of Sciences, 98, 5404-5410. doi:10.1073/pnas.101092798 
Rowe, R. J. (1978). Ischnura aurora (Brauer), a dragonfly with unusual mating behaviour (Zygoptera: Coenagrionidae). Odonalologica, 7, 375-383.

Rowe, L., Arnqvist, G., Sih, A., \& Krupa, J. J. (1994). Sexual conflict and the evolutionary ecology of mating patterns: water striders as a model system. Trends in Ecology \& Evolution, 9, 289-293. doi:10.1016/0169-5347(94)90032-9.

Samways, M. J., Caldwell, P. M., \& Osborn, R. (1996). Spatial patterns of dragonflies (Odonata) as indicators for design of a conservation pond. Odonatologica, 25, 157-166.

Siepielski, A. M., \& McPeek, M. A. (2010). On the evidence for species coexistence: a critique of the coexistence program. Ecology, 91, 3153-3164. doi:10.1890/10-0154.1.

Sirot, L. K., \& Brockmann, H. J. (2001). Costs of sexual interactions to females in Rambur's forktail damselfly, Ischnura ramburi (Zygoptera: Coenagrionidae). Animal Behavior, 61, 415-424. doi:10.1006/anbe.2000.1605.

Sisodia, S., \& Singh, B. N. (2012). Experimental evidence for nutrition regulated stress resistance in Drosophila ananassae. PloS one, 7(10), e46131. https://doi.org/10.1371/journal.pone.0046131.

Stewart, A. J. A. (1996). Interspecific competition reinstated as an important force structuring insect herbivore communities. Trends in Ecology \& Evolution, 11, 233-234. doi:10.1016/0169-5347(96)30009-8

Waage, J. K. (1987). Choice and utilization of oviposition sites by female Calopteryx maculata (Odonata: Calopterygidae). Behavioral Ecology and Sociobiology, 20, 439-446. doi:10.1007/BF00302987. 